\title{
The Blank Slate E-State: Estonian Information Society and the Politics of Novelty in the 1990s
}

\author{
ARO VELMET \\ UNIVERSITY OF SOUTHERN CALIFORNIA
}

\begin{abstract}
This article looks at how the discourse of an emerging information society in 1990s Estonia both rejected and depended on expertise from the Soviet Period. It traces the influence 1960s-trained cyberneticians and sociologists had on expanding the concept of an information society in the 1990s, to encompass issues such as regional inequality, national culture, and poverty, instead of focusing solely on hardware purchasing and telecomms liberalization. This process was both enabled and occluded through "rupture-talk," a rhetorical strategy emphasizing the novelty of digital infrastructure development compared to the Soviet past. The article argues that a shared belief in the power of information processing for both empowering and containing civil society enabled ideologically divergent actors to work together. The resulting vision diverged from neoliberal visions of information societies in hitherto unacknowledged ways.
\end{abstract}

\section{Keywords}

Eastern Europe; late socialism; neoliberalism; cybernetics; computing; education; development

\section{Introduction}

In recent years, Estonia has become known as a "digital republic," featured in publications ranging from The New Yorker and Foreign Affairs, to The Guardian and The New York Times (Crouch 2015; Heller 2017; Chakravorti et al. 2015; Keen 2016; Scott 2014). Usually, such articles highlight the efficiency of Estonia's digital public services, from e-tax filing to e-voting, promote possibilities for business innovation through programs like e-residency, and celebrate the country's contribution to popular apps such as Skype or Transferwise. Ambassadors of the digital republic (which include entrepreneurs, expat intellectuals, and former and current presidents) often attribute Estonia's digital success to exploitation of the technological gap created by the fall of the Soviet Union. Commentators describe this moment as a "historical accident, which [...] meant [Estonia] had to establish new systems with new people and technologies," (Scott 2014) and "build their new country from scratch [jumping] from typewriters to the latest web-connected computers" (PBS

'Aro Velmet, Email: velmet@usc.edu

Copyright ( 2020 (Aro Velmet). Licensed under the Creative Commons Attribution Non-commercial No Derivatives (bync-nd). Available at estsjournal.org. 
Newshour 2018). According to this narrative, the shock of the post-Soviet transition created both a need for quick economic development and a desire for a more open, democratic society, both of which were achieved through digital transformation (Kimmo et al. 2017; Velmet 2016). Further accentuating the idea of a profound rupture with the past, the reader will quickly come across numerous comparisons to Silicon Valley, not simply as a convenient shorthand for "tech heaven," but as a set of values oriented around minimal bureaucracy, entrepreneurial risk-taking, an embrace of quirky ideas, a rhetorical commitment to transparency, and the conviction that all of these qualities put in the service of ICT development in a free market will bring about a more democratic society (Heller 2017; VentureBeat 2018; Sampere 2016; see Turner 2006 for the history of this constellation).

A growing body of scholarly work has critically interrogated Silicon Valley-centered theories of digital innovation and democratic government. In the Western context, some historians have highlighted how post World War II "decision sciences" connected to the development of computing-cybernetics, operations research, rational choice theory, etc.--underpinned a rethinking of the role of information in government. This reframing, which could most succinctly be described as a substitution of deliberative, public reasoning with calculative, impersonal, algorithmic rationality has in the past half century penetrated a stunning array of governmental sciences from neoliberal theories of the state and international relations theory, to bureaucratic management and urban planning (Mirowski and Nikh-Khah 2017; Mirowski 2001; Guilhot et al. 2019; Light 2003; Edwards 1996; Erickson et al. 2013). Others have nuanced this history by extending its origins beyond the Cold War military-industrial complex to 1960s counterculture and challenging the degree to which the age of information has really dethroned deliberative reason (Turner 2005; Abbate 1999; Castells 2010).

Meanwhile, scholars working on the Global East and the Global South have written innovative counter-histories of computing, providing alternatives to "the market as information processor" and "Cold War closed world" theses centering on the role of the United States. Latin America, in particular, has become a fruitful ground for exploring local entanglements of innovation, technology, and power, with scholars looking at projects ranging from automated control systems for the management of socialism (Medina 2011) to the One Laptop Per Child program (Ames et al. 2010; Medina et al. 2014). In the African context, scholars have looked at how the apartheid regime in South Africa pioneered now globally ubiquitous forms of biometric identification (Breckenridge 2014) or how radio and cinema introduced by colonial authorities mixed with postcolonial nationalism and Islam to produce a complex urban landscape of popular media in Nigeria (Larkin 2008). Finally, scholars of the Soviet Union have looked at how cybernetics was used to reimagine socialist civil society, central planning, architecture, and economics in ways that differed from the West in both form and content (Gerovitch 2002; Peters 2016 Kurg 2019; Leeds 2016). Digital government à la Silicon Valley by way of the RAND Corporation and the Whole Earth Network was clearly not the only project on offer in the twentieth century.

Here's the rub: even counter-histories drawn from the Eastern Bloc or the global South have ultimately reinforced the idea of a rupture, both geographically, between the American 
mainstream and global alternatives, and also temporally, before and after 1989. For example, histories of Soviet cybernetics are written essentially as histories of failure. While historians acknowledge their shared roots in the works of Norbert Wiener and the nuclear arms race, they are portrayed as developing essentially on parallel tracks (Erickson et al. 2013; Peters 2016; an exception is Rindzevičiūte 2016). Moreover, such histories end roughly in the Brezhnev age or perestroika at the latest. As tools of reforming the Soviet state, "cyberspeak and computer technology [were appropriated] as means of conserving the existing administrative hierarchies" (Gerovitch 2002), while OGAS, the Soviet attempt at internetworking, was killed by a lack of coordination and too much internal competition (Peters 2016). Americans built the Internet, the Soviet Union had an Internyet, the argument goes. Similarly, post-1989, digital government projects in the East are seen as part and parcel of neoliberal expansion, driven primarily by Western telecoms, EU accession criteria, and liberalizing technocrats, and enabled by the scorched earth left in the wake of the Soviet collapse (Ther 2016; a notable exception is Weekes 2019). Like e-state projects in the UK or the US, governmental computer expertise in the post-Soviet East was outsourced to private companies and used often (and largely unsuccessfully) to reduce "waste" and bureaucracy (Agar 2003; Margetts 1998; contrast to Mailland \& Driscoll 2017). Such narratives echo economic histories of the post-socialist sphere focused on the role of "the Chicago boys" and various international institutions, which demanded sophisticated expertise that local elites simply did not have (Johnson 2017). At stake, then, is whether the global history of computing is told as one of Western victory and the globalization of the Silicon Valley model, with non-Western experiments providing glimpses of possible but ultimately futile alternatives, or whether a more tightly interwoven history can exist.

The birth of Estonia's "information society" in the late 1980s and early 1990s points towards such a history. Estonian politicians, foreign investors and international organizations all asserted the novelty and Western provenance of digital infrastructure in the 1990s. In reality neither the ideology nor expertise used in these projects fit the bill. The hardware was Western, this much is true: phone lines and cables were updated, IBM computers running Windows operating systems appeared in both public and private offices. Actors at the time equated the novelty of the "information age" with the Western provenance of hardware. The actual deployment of this hardware, however, depended on the expertise of sociologists and cyberneticians educated in the Soviet system. A more expansive concept of "infrastructure," which incorporates the technical know-how, cultural competences, and legal frameworks required to make this hardware function (Barry 2001; Hughes et al. 1987), unveils critical continuities with the Soviet period. This ideologically and materially complex "information society," as it emerged in the 1990s through well-publicized projects like The Tiger's Leap, institutions such as the State Informatics Council, and democratic deliberation initiatives like Today, I Decide, was skeptical of market rationality, attentive to questions of regional and informational inequality, and ready to wield state power to contain the interests of multinational telecoms and ICT firms. These principles were in constant tension with a more enthusiastic embrace of information technology in the service of the market and were, in any case, highly circumscribed in a political environment overall very sympathetic to the Chicago Boys. Still, the groundwork for the "digital republic" was laid as much by Soviet- 
trained cyberneticians and sociologists as it was by Western-educated visionaries, making the separation between the West and the rest in histories of digital government impossible to sustain.

The article makes two conceptual points about the political role of "information age" discourse in this transitional moment. First, I argue that we should think of the post-1989 rupture not as a historical fact, but as "rupture-talk" (Hecht 2012), a discursive tool that reformers used strategically to position their projects as distinctly different from Soviet statecraft. Claims about the arrival of a new age in which "everything is different," were used to render digital infrastructure development an "exceptional" issue, outside the bounds of normal political debate. Such framing enabled e-state visionaries, for instance, to secure funding for investment even in times when the state was struggling to pay for pensions and teachers' salaries. Digital rupture-talk also helped bind questions of ICT development to the very future of the nation. Yet what actually defined the boundaries of digital things was up for grabs. Was it just computers? Or did the living conditions of computer users (such as teachers and library workers) or the conditions of access (for example in the countryside) also constitute a part of the "information society?" Could social policy or regional development also become a part of the discourse on digital exceptionalism? Claims to novelty alone could not answer such questions. They had to be debated and fought over.

Thus, discussions of "information society" created a space where experts and activists could discuss concerns that were otherwise considered ideologically suspect-most often as too "socialist." Here, social scientists, teachers, and cultural figures, who worried about the effects of market liberalization on Estonian culture, the education system, regional inequality and poverty, could gain a hearing alongside representatives of Western telecoms and German free-market think tanks. At a moment where national politics were dominated by market fundamentalists, information society discourse offered more capacious language. Digital development in the postSoviet sphere has too easily been cast as a form of anti-politics and a way for technocratically imposing neoliberal reforms (Ferguson 1994; Annist 2011). In the Estonian case, the debate actually expanded the range of possible policy options, and enabled a range of actors to voice their views and influence decisions.

The article proceeds in three parts, drawing on archival research, a plethora of articles, academic studies, and 20 interviews with various stake-holders (policy-makers, scientists, cyberneticians, public servants, educators) conducted in 2017 and 2018. First, it surveys the emergence of cybernetics and "concrete sociology" as two fields where digital utopianism was first articulated in the Soviet Union in the 1960s and onwards. The second section looks at how 1990s reformers, affiliated with the Soros Foundation and the United Nations Development Programme, emphasized rupture with the Soviet past as the key component of an emerging Estonian information society, while working closely together with experts whose formation lay precisely in that past. Finally, the third section analyzes the Tiger's Leap, a project to computerize Estonian schools, showing how talk of the information society expanded to encompass a variety of issues that fell outside of the free-market mainstream. Rather than seeking to establish a "correct" history of continuity to replace narratives of rupture, this essay seeks to chart the diverse narratives reformers have told about the early days of "e-Estonia," paying attention to why some narratives had more political purchase than others, and how arguments about the novelty of the e-state were 
adopted even by reformers who simultaneously saw themselves as building on competences acquired in the 1960s and 1970s.

\section{The Birth of the Information Society in Soviet Cybernetics and Sociology}

Many 1990s advocates of the information society came from two local intellectual traditions: Soviet cybernetics and sociology. Though members of these disciplines styled their Soviet era activities often as almost dissident in orientation, both cybernetics and sociology were born in and supported by the official structures of Soviet government. The importance of cybernetics in late socialist governance in now well known. Originally considered a "bourgeois unscience," cybernetics was quickly rehabilitated during the Khrushchev era. Many reformers were enthralled by the mathematical language of cybernetics, which reformulated social problems in seemingly objective terms of "feedback," "control," and "non-linearity," providing a technocratic alternative to otherwise contentious and politicized questions of social organization (Gerovitch 2002). The discipline was critical to military development and by extension to Soviet supremacy in the Cold War. Soviet authorities even attempted (unsuccessfully) to create a pan-Union network of computers to solve the country's economic coordination problems-a kind of Soviet Internet (Peters 2016). By the end of the 1960s, cybernetics had penetrated all aspects of Soviet policy discourse--and, in the process, been thoroughly neutralized of its reformist potential, becoming, as Slava Gerovitch has argued, a formalist language used to justify existing bureaucracies and status quo, thereby losing its appeal both with scientists and would-be reformers.

In peripheral regions such as Estonia, where official institutions were more flexible, intellectuals used the language of cybernetics to secure funding for diverse passion projects, which used computation primarily for research in the natural sciences, and only partly in industry and social sciences. In 1960, the Estonian Academy of Sciences founded the Institute of Cybernetics (IoC) in Tallinn, which researched fields ranging from speech synthesis, mathematical methods, economic cybernetics, automated control systems, and artificial intelligence to linguistic cybernetics, physics, chemistry and architectural modeling (Kutser 2000). The Institute's staff praised the virtues of cybernetic interdisciplinarity, and fulfilled contracts for big industrial state enterprises, the defense industry, the local Planning Committee, and various municipal organizations. At the same time, researchers at the IoC largely self-identified as apolitical, and uninterested in questions of social reform, focusing instead on specific industrial or engineering problems and basic research. Indeed, many seemed to regard the term cybernetics as simply an umbrella term for the mathematical sciences, and the IoC as primarily a hub of academic research with comparatively more independence and fewer "mandatory ideological activities" than a university department. ${ }^{2}$ The IoC established an institutional basis for computing expertise ranging from programming to hardware construction-expertise that would prove critical during the glasnost period.

2 Hillar Aben, interview with the author, April 12, 2018; Jüri Engelbrecht, interview with the author, April 13, 2018. 
Computing returned to a Soviet reform agenda with Andrey Ershov's "second literacy" project in the mid-1980s. Writing in Pravda, Ershov argued that the widespread use of personal computing would reduce the role of the bulky Soviet bureaucracy, improve private initiative, and lead to the "democratization of the information structure of society" (Ershov 1988). The introduction of personal computers and programming classes to compulsory education would catalyze this process. These ideas were partly inspired by Ershov's contacts with engineers and visionaries in the United States--particularly with Seymour Papert at MIT—as well as by the works of V. G. Afanasyev, and the Soviet "father" of cybernetics, Aksel Berg. Ershov believed that universal education in programming would, much like regular literacy education, create a new intellectual elite, and endow children with the skills needed in a future economy dominated by automated control systems. Pupils would acquire universally useful abilities such as "an active life position," "the ability to develop a program of action and follow it," and algorithmic thinking (Afinogenov 2013). With the arrival of Mikhail Gorbachev's age of perestroika, the project received official endorsement and was made compulsory in all schools.

The USSR now faced a demand for large numbers of personal computers. It could not deliver them. In Estonia, experts and policymakers were concerned that educational reforms would reduce the importance of Estonian language, and accelerate what was largely perceived as a process of Russification (Velmet 2019). Engineers at the IoC were invested in developing PCs not simply in order to demonstrate their professional skills but also because local production would ensure that school computers would have Latin, rather than Cyrillic, keyboards and run software in Estonian or perhaps English, but certainly not in Russian. ${ }^{3}$ IoC engineers developed a prototype for a school computer, Juku, and a local radio electronics manufacturer, Baltijets, produced around 2,500-3,000 computers by 1991 (Kanger 2013). By the time they were delivered to schools, the computers were outdated even by Soviet standards. Still, the attendant PR campaign, the training of programming teachers, and the institution of programming classes using pen and paper established the idea of computing as a source of social reform and its implementation through the educational system in the minds of policymakers and the lay public alike.

Cybernetics emphasized the potential of automated planning for economic development. By contrast, sociologists working in Leningrad, Tartu, Kiev, Sverdlovsk, and elsewhere in the USSR used theories that combined cybernetic insights, Western mass media studies, and Marxist-Leninist philosophy to argue for the necessity of mass data processing and citizen feedback for the development of an urbanized, industrial society. Like cybernetics, the rehabilitation of sociology after the Stalinist period responded to the massive coordination problems faced by Soviet central planning authorities. These ranged from GOSPLAN in Moscow to local planning committees in the Republics, as well as specific firms and municipal governments facing the challenges of migration, population growth, and the associated demand for housing and services. Ensuring that

${ }^{3}$ Ülo Jaaksoo, interview with the author, Feb 28, 2018.

* For instance, almost all computing teachers, activists, and policy experts who participated in the 1990s reforms named playing with Juku as a part of their formative experience. Märt Põder, interview with the author, Feb 2, 2018; Mari Käis, interview with the author, May 7, 2018; Riina Einberg, interview with the author, 9 May, 2018. 
sociological research would not impinge theoretically on the territory of Marxism-Leninism, official institutions-the CPSU and the Soviet Academy of Sciences--endorsed "concrete sociology" designed to provide planners with information about the people's work habits, lifestyles, and media consumption. The Academy of Sciences founded the Soviet Sociological Association in 1960 and a year later sociological studies were being conducted in Moscow, Leningrad, Sverdlovsk and the Moldavian Socialist Republic (Osipov 2009).

Estonia became a locus of sociological work in the USSR partly because of its proximity to St. Petersburg's Sociological Laboratory and the Faculty of Philosophy, where many prominent Estonian researchers were educated. Estonian universities were not considered federally critical institutions and were subject to less oversight, the language barrier inhibited certain forms of surveillance, and the head of the Estonian Communist Party, Johannes Käbin, permitted more local autonomy. As a result the country became an attractive destination for a range of heterodox thinkers across the USSR, ranging from self-described "sixties idealist" Marxists to researchers such as Yuri Lotman, who fell out of favor in the metropole and were effectively exiled to "the Soviet West" (Danilova et al. 2009). Sociologists Vladimir Iadov, Boris Firsov and Yuri Levada held lectures at the Kääriku sports center, and Iadov's lecture notes became the principal textbook for a cohort of Estonian sociologists. A few years later, the Kääriku notes were circulating across the Soviet Union (Iadov 1970; Iadov 1972).5 In 1967, Ülo Vooglaid received permission to start a Sociological Laboratory at Tartu University, which, along with computing centers at the Estonian Radio and a working group at the Academy of Sciences reinvigorated sociology in Soviet Estonia. Iadov connected his theory to the requisite works of Marx and Lenin, but drew equally from American theorists, most notably Robert Merton and Talcott Parsons, as well as from Norbert Wiener. For him, sociological research was necessary for "holistically" understanding "complex processes" in a "mass society," and solving problems that required wider expertise than economists, psychologists, or politicians alone could provide. The job of sociologist was therefore, on the one hand, to provide practical input for managers and planners. On the other hand, sociologists had to collect and interpret feedback from people influenced by Soviet policy, ranging from reactions to labor reorganizations at collective farms, or the reception of ideological communications in the editorials of Pravda (Iadov 1972).

Much of the research at USSR's sociological laboratories focused on the sociology of "social values"--how individuals' goals in work and private life differed from those articulated by the state. Such studies consistently found the two to be wildly divergent (Shlapentokh 1982). In Moscow, sociologists studied the reading habits of Pravda subscribers and found readers to be more interested in sports and funny pages than in official editorials; in Tartu, Vooglaid came to similar results in his studies of the local communist paper of record, Edasi. Vera Vodsinskaia's studies of high school graduates found that students were interested in high-paying, high-prestige jobs and not jobs that were considered socially useful (ibid). Iadov, Vooglaid, and others interpreted such discrepancies in cybernetic terms, as problems of effective mass communication--the state was

s Ülo Vooglaid, interview with the author, Oct 232017. 
neither transmitting its own priorities successfully to the population nor even properly aware that its messages were not being received (Iadov 1972; Lauristin 2010).

By the 1970s, sociology textbooks published at Tartu began to emphasize the importance of feedback (one of the central categories for cybernetics) in ideological education through television, radio, and publishing. They noted that mass communication had to meet the needs of its audience, be attractive, and easy to access, if it was to be effective (Lauristin \& Vihalemm 1977). Increasingly, sociologists interpreted communication as a two-way phenomenon, and highlighted the importance of feedback for overall social stability. Thanks to the availability of computer mainframes, sociologists could facilitate these feedback processes: collecting public opinion through increasingly sophisticated survey methods, and transmitting it back through mass media. Working with ecologists at Tartu University, sociologists used URAL-IV mainframes to develop complicated taxonomies of newspaper readers and consumers in order to better classify their habits and values with the stated intention of calibrating state responses to better match actual demand (Lauristin 2010). Like American public opinion surveys that directly inspired this sort of work (Igo 2008), Soviet sociologists saw themselves empowering democracy through empirical description; unlike their American counterparts, they were less interested in describing a "normal" or "typical" citizen, and more interested in charting diversity; less interested in market research and more focused on cultural interests (such as theatre-going habits or literary interests) and attitudes to labor; less sanguine about the ability of information to speak for itself on a public marketplace and more insistent on the role of expert reason in interpreting the results. Facilitating two-way communication through digitized surveys, sociologists thought, would make Soviet society more democratic, while retaining the role of agenda setting and processing for the sociologists themselves.

The Sociological Laboratory at Tartu University was closed in 1975, ostensibly due to "the overall increase in ideological control in the USSR" (Lagerspetz 2007), though individual accounts suggest interpersonal conflicts within the University as the proximate cause. ${ }^{\text {The }}$ The staff of the Laboratory moved on to other universities, but continued working in the field, by collecting and processing public feedback on big development projects. Mati Heidmets set up a team at the Tallinn Pedagogical University that surveyed residential experiences in new mass housing projects, advising central planners in Georgia, Ukraine, Uzbekistan, and elsewhere (Heidmets et al. 1983). At the Tartu Agricultural University, Asser Murutar conducted studies of land use patterns and local farming methods commissioned by collective farms (Murutar 1995). Marju Lauristin, working at the Department of Journalism at Tartu University, led a series of studies on environmentalist attitudes, collecting data on public opinion that were widely used during the first glasnost-era protests against industrial mining in Eastern Estonia (Lagerspetz 2007). The success of these projects, which moved from processing data for state development projects to building up

- Ülo Vooglaid, interview with the author, Dec. 6, 2017; Marju Lauristin, interview with the author, April 12, 2018.

'Mati Heidmets, interview with the author, May 28, 2018.

: Ülo Vooglaid, interview with the author, Dec. 6, 2017; Marju Lauristin, interview with the author, April 12, 2018. 
coalitions against Moscow, established sociologists as important elites. Cybernetics-influenced concepts of mass media, feedback, and two-way communication became central to imagining future forms of complex civic societies.

\section{Information Society as the Solution to Post-Socialist Development}

In the late 1980s, state and educational institutions in Estonia began to orient themselves away from Soviet ICT and turn towards the West. They purchased IBM PC-s, began to build national databases that used Western standards, and established first connections to Usenet, FIDOnet, and the Internet. In part, these changes were driven by technological necessity-Soviet PC-s were increasingly obsolete, underpowered, unreliable, and difficult to repair because of the low grade of materials used in construction and a lack of spare parts. As academics at Tartu University and the IoC established partnerships with universities in Finland and Sweden, they needed faster communications to maintain these collaborations and established electronic links to Finland, primarily through the company Elorg-Data. Other cyberneticians took advantage of perestroika-era economic liberalization and the legalization of small private enterprises, establishing joint ventures with companies in countries ranging from Finland to the US (Kübi Aastaraamat 1990). Finally, as part of the nationalist reform movement "Self-managing Estonia," state leaders established a new Informatics Council and an adjacent "Informatics Development Fund," tasked with building up state databases and self-sufficient administrative systems. Their goal was to integrate Estonia to Western standards, and "establish and coordinate a common informational development strategy for the ESSR.",

Initially, these efforts were limited by a lack of interest from policymakers, who gestured towards the "importance of the informational sphere," but were unwilling to commit funds to its development. Estonia did not establish its first connection to the Internet until 1992, a year after the restoration of the country's independence. By 1996 the country only had 2 internetworked computers per 1,000 residents--a tiny number compared to 25 in the US, or Finland's world leading 45 (Eesti Ekspress 1996). Initial changes were slow, and, aside from cyberneticians who had migrated to public service and academics seeking connections to Western universities, few experts conceived of ICT as a source of economic or civic progress.

In the second half of the 1990s, talk of "information society" re-emerged as an ideological and budgetary priority for state reformers. The sources of this development were manifold. First, multinational telecom companies and local banks, who wanted improved infrastructure and legislative changes to facilitate business in Estonia, made information age transition the cornerstone of their rhetoric. Independent Estonia had retained state monopolies over its telephone and data networks, the former being administered by the state enterprise Eesti Telefon, and the latter through the academic ISP EENet, which provided Internet connections free of charge. Nordic telecoms saw Estonia as a fertile ground for investment, as well as a convenient platform for

- Eesti NSV Ministrite Nõukogu Asjadevalitseja T. Järve juures toimunud töönõupidamise protokoll, Nov 2, 1989, Informaatikanõukogu 1/1-4/1, Information System Authority Archives (RIA-A), Tallinn, Estonia. 
learning about Soviet-era telecom infrastructure in preparation for further expansion into the East. In order to make inroads into the Estonian market, however, these firms wanted the state to liberalize its telecommunications sector. Meanwhile, Estonian banks were developing novel, inhouse phone and computer-based services, which required reliable phone lines (still a rarity in parts of rural Estonia), and access to the Internet, which state monopolies were in no rush to provide (Högselius 2005). Working through direct connections to policymakers, as well as through liberal think tanks such as the German Friedrich-Naumann-Stiftung, investors began promoting the idea of an information society as part of their broader expansion strategy into the Baltics (Friedrich-Naumann-Stiftung 1996).

International organizations and charities, in particular the United Nations Development Programme, the European Union and George Soros' Open Society Foundation, became equally important sources of information society discourse. In the 1990s, much of Estonia's development agenda was driven by the availability of foreign funds, as the country itself struggled with rampant inflation and the difficulties of adapting to a market society. Organizations such as Open Estonia Foundation shaped local policy agendas in two ways: first, by providing bursaries and travel grants for local experts to study abroad or meet with foreign experts; and second, by directly financing programs that ranged from supporting the arts and publishing cultural magazines, to the purchasing of hardware and constructing web sites for civil society and cultural organizations across the country (Rebane 2011). These investments cohered with George Soros' Popperinfluenced philosophy of history, which emphasized actively building "open societies" in the former Soviet bloc through the training of local experts in Western firms and public offices, and financing institutions that supported critical education and the open exchange of information (Soros 1990).

Finally, as part of European integration programs and general state building efforts, policymakers and social scientists compiled studies comparing Estonia's development with those of Western countries, and imagined ways of moving forward. Some of these studies were run under the aegis of UNDP (The Estonian Human Development Report), others as part of Agenda 21 (Säästev Eesti 21), others still as part of EU accession procedures (the Phare programme). These studies, while commissioned or funded by international organizations, were shaped largely by the intellectual interests of Estonian social scientists trained in the Tartu sociology laboratory and its offshoots. Powered by the reputation of these experts, many of whom had become better known as 1980s liberation activists, and a desire for optimistic visions of the future, discourses of the information age made its way to popular media, where pundits and experts debated how Estonia might one day reach Western living standards, and rebuild a sustainable national culture. However, in these local interactions, the promise of an information age took a very different ideological bent from the argumentation advanced by early reformers and Western multinationals.

Western telecoms and liberal think tanks emphasized the importance of breaking with Soviet patterns of state planning and economic development, contrasting the agility and adaptability of economic liberalism with the cumbersome and ineffective centralized bureaucracies of the Soviet regime. "The information society of tomorrow," as a representative of the German Friedrich-Naumann-Stiftung put it, "promises more freedom, more pluralism, more individualism 
[...] the state's ability to control will be diminished. Individual and economic has to be organized through greater individual responsibility and voluntary mechanisms of self-control" (FriedrichNaumann-Stiftung 1996). Instead of centrally planned standards, liberal development would focus on voluntary adoption. Instead of state-driven investment (which would reproduce Soviet-style corruption), information society would work in cooperation with private companies (Lang cited in Friderih-Naumann-Stiftung 1996). In practice, these principles were codified in documents such as the "Principles of information policy," which set the priorities for state ICT development, and emphasized "the creation of a competitive economy, particularly through demonopolization, acceleration of property reform, and the development of electronic communication and banking" (Riigikogu 1998).

For Estonian policymakers and visionaries, breaking with the Soviet past meant avoiding corruption, and embracing democratic transparency that widespread access to ICT would provide. Here, Soviet information policy was portrayed as unidirectional, vertical, and Orwellian. According to one futurist vision,

in former socialist states, telecommunication infrastructure followed very precisely the logic of the political process: one-way vertical communication was more developed than opportunities for multidirections horizontal interaction. People had more TV-sets than telephones. Information disseminated from the center had to reach viewers/listeners, whether they could discuss the problems afterwards was unimportant. Politically it was rather unwelcome. One legend has it that J. Stalin considered the telephone a counterrevolutionary weapon. (Eesti Inimarengu Aruanne 1996)

Moreover, the development of interactive ICT tools would also reduce the corruption and mendacity that had characterized the Soviet system and that ICT enthusiasts saw in the practices of many entrepreneurs who took advantage of the post-Soviet moment. In particular, information society could address the problems of privatization, which many local pundits saw as benefitting the well-connected and former Soviet bureaucrats. Critics of privatization portrayed the process as packed with get-rich-quick schemes, as defrauding regular citizens, and bordering on the illegal-more "cowboy capitalism" than the road to prosperity that advocates of free market shock therapy had promised. Critically, the failure of privatization was seen as consequence of the Soviet legacy, rather than a problem with the capitalism itself (Langemets 1994). If every citizen had access to the Internet and was properly educated in its use, the logic of information society visionaries went, then they would be equipped to check on the activities of state bureaucrats and business leaders, and prevent corruption through transparent oversight..$^{10}$ To achieve this, the education system would have to become a particular focus of ICT development (Ilves 1995; Praust 1996; Tammet 1997).

The leapfrogging argument connected Soviet-era underdevelopment to the promise of future prosperity. Here we begin to see how information society visionaries used rupture-talk to articulate an alternative to Western development, in some instances clashing with the vision of

10 Linnar Viik, interview with the author, Nov 2 2017, Tallinn, Estonia. 
international organizations. The shock of the post-socialist transition could be used to catalyze the information age transition, as one expert at the Ministry of Education argued: "Governmental structures have not yet ossified, mechanisms for guaranteeing social welfare have not yet been developed, the infrastructure needs to be rebuilt anyway. We are looking at a period of reconstruction, without having to demolish first. [...] and what is more, the Soviet period has taught people to find information within the noise" (Ruut 1996). Building a digital public sector, with computerized databases and paperwork, for instance, was seen as "far more modern, than in countries where [public administration] is already set" (Rumm 1998). IT engineers, too, praised Estonia for its lack of "socialist Western legislation" (ie., an expansive welfare state) and argued that a digital turn would prevent the thick layer of bureaucracy required to administer a welfare state from ever even forming, thereby giving the country a natural competitive advantage (Aedla 1996). Visionaries admitted that this future-oriented rhetoric was primarily a myth for surviving present deprivation, akin to the 1980s struggle for independence (Ilves, quoted in FriedrichNaumann-Siftung 1996).

Social scientists reproduced rupture-talk, but were more concerned with the potential downsides of a poorly managed, overly liberal approach to ICT development. Without scientific forecasting, they argued, Estonia could fall into the hands of "transnational infogiants," middleaged and older generations could be left behind, and present day social welfare needs might be ignored. Estonia did not need simply any kind of ICT infrastructure; it had to be properly planned and executed. Only then could an information society offer solutions to social welfare problems. Through increased connectivity and faster information exchange, computerization could prevent uneven regional development, which sociologists depicted as a quintessentially "Western" problem. ICT would provide new opportunities for the disabled, working mothers, and the vast numbers of people left unemployed by the collapse of collectivized farms in the Estonian countryside (Lauristin cited in Friedrich-Naumann-Siftung 1996; Liiva 2001; Aaviksoo 1996).

A second issue fraught with both danger and opportunity was national culture. Here, too, sociologists cautioned against an overly liberal approach. Global connectivity might promise economic benefits, but it also represented a threat to cultural diversity and national culture. "Would Estonian culture and the Estonian language not dissipate in this globality? Will we not abandon our identity and national sensibility in the information society?" (Eesti Inimarengu Aruanne 1996). These concerns mirrored those expressed by skeptics of the 1980s second literacy projects, with global English taking the place of Soviet Russian as the linguistic bogeyman." Yet social scientists also saw new opportunities, again, if guided by proper expert management. By making media studies a central part of the school curriculum, writing educational software in Estonian, and focusing on the development of national culture online-through initiatives such as folklore databases, online editions of the Estonian national epic "Kalevipoeg," and websites for Estonian schools-students could be educated to engage critically with online content, and ICT would work to boost national culture, rather than dilute it."

"See also "Informaatikanõukogu istung" March 16 1997, Informaatikanõukogu 1.1-4.4, RIA-A; and “Tiigrihüppe aastaraamat 1997," ERA.5602.1.2, Estonian National Archives (RA), Tallinn, Estonia.

12 "Tiigrihüppe aastaraamat 1998," ERA.5602.1.4, RA. 
By 1997-1998, largely through the work of social scientists and forecasters like Marju Lauristin and Erik Terk, "the information society" had turned from a series of haphazard talking points used largely to justify liberalizing the telecoms market into a unified strategy for Estonia's development. Social scientists began to contrast a well-managed and expert-led "information society" with other development paths, which resulted in more inequality and less prosperity. Estonia could become "a borderland, which is "within' [Europe] but, by doing everything as others have done, cannot overcome its substantial underdevelopment."s One influential report laid out four different development scenarios, most of which described some form of uneven development (becoming a source of cheap labor for wealthy Scandinavian countries was called the "Southern Finland" scenario), while the most desirable scenario ("The Grand Slam") envisioned a universal well-educated and high-tech workforce capitalizing on ICT advancements (Terk \& Raagmaa 1997; Eesti Inimarengu Aruanne 1999; Oja \& Raukas 1999). While these scenarios acknowledged the importance of liberal reforms, they equally highlighted the importance of state-led investment and planning, which would ensure that ICT infrastructure was distributed equally, prioritized national culture, and brought educational improvements to the entire population. This was quite different from the decentralized, liberalizing projects of a few years earlier.

Indeed, while information society visionaries strategically described the arriving age as a break with the Soviet times, their visions built upon ideas and institutions originally formulated in the 1960s-1980s. Indeed, it was primarily the two strands of Soviet reformists-cyberneticians and sociologists--who pushed back against efforts at liberalizing ICT infrastructure and education development, demanded more state oversight, more centralization, and greater attention to questions of inequality, equal access, and national culture. They were in a position to do so. In 19881991, the IoC lost a majority of its staff, going from 600 employees in 1988 to less than 100 in 1996 (Kutser 2000). A majority either moved abroad, becoming engineers and developers in Finland or Sweden, or started companies in Estonia. Many influential figures, however, made their way into the public sector, taking up advisory positions in the State Chancellery, the nascent Information Systems Agency or in various ministries that dealt with data processing. Of particular importance was the IoC dominated Informatics Council, founded in 1989, in the midst of Perestroika, which remained the state's ICT advisory board until the early 2000s. It was the Informatics Council, which advocated for coordinated ICT development across the public sector, monitored public tenders for the purchasing of computers, and cautioned against an overly hardware-centric approach, emphasizing instead the importance of education and expertise building."

Similarly, sociologists educated in Vooglaid's Sociology Laboratory found that their expertise in media studies was easily adapted to the rhetoric of the information society. Concerns over inequality, which were politically controversial at the time, could be voiced with greater ease, and with the backing of international funders, in the context of debating Estonian's development

\footnotetext{
${ }_{13}$ “Tiigrihüpe kui Eesti sotsiaal-majanduslik katalüsaator, 1998," ERA.5602.1.4, RA.

${ }^{14}$ For ex. See the discussions over public tenders and mass hardware purchases on June 251992 , Informaatikanõukogu 1.1-4.1; on the development of informational policy strategy on Jan 251994 , Informaatikanõukogu 1.1-4.2; on the Tiger's Leap program March 3 1988, Informaatikanõukogu 1.5-6.5, RIAA.
} 
strategies. Some had prior careers in high politics-Marju Lauristin served as a minister of the Social Democratic party in a liberal-nationalist dominated coalition agovernment. These stints, however, ended largely in disappointment. Lauristin, for example, had to defend pension cuts in a neoliberal government and suffer media attacks that highlighted her links to the communist regime (Lauristin 2010). As information society experts, however, she and other sociologists could draw on three decades of local research on media studies and consumption patterns, relate them to theories formulated by Western academics (such as Manuel Castells), and retain their focus on policy, education, and problems of inequality while appearing to pursue a project that was perceived widely as ideologically anti-Soviet.

Rupture-talk did political work in different ways: first, it brought together several disparate projects--from the liberalization of telecomms infrastructure, the construction of public sector databases, computerizing public administration, to reforming the education system-under a single narrative. This myth could be used to energize the public and build political support for investment projects that might otherwise be deprioritized over more pressing present-day concerns such as teachers' and nurses' salaries. It empowered a set of experts who might otherwise have found themselves marginalized because of their background in high-profile Soviet institutions. Finally, rupture-talk helped set Estonia apart from the West, and supported local actors' vision of an Estonian sonderweg, that was enabled by the institutional and infrastructural chaos brought about by the fall of the Soviet Empire. Estonia's development did not have to replicate the model of Western welfare states, which appeared increasingly outmoded; but neither did local policymakers have to adopt wholesale the suggestions of companies like IBM or Telia, or liberal think tanks like the Friedrich-Naumann-Stiftung. Within the rubric of the information society there was surprisingly much room for internal debate. In what follows, we will look at how the theory of building an information society was put into practice in the form of the Tiger's Leap, a high-profile program for computerizing Estonian schools.

\section{Transformations of the Tiger's Leap}

In 1995, the Estonian ambassador to the United States, Toomas Hendrik Ilves, and the minister of education, Jaak Aaviksoo, proposed a visionary "technological challenge for Estonian schools," called the Tiger's Leap. The name suggested that Estonia might become a successor to the booming high-tech Asian Tigers of Singapore, South Korea, Hong Kong, and Taiwan." The project began as a vague set of lofty proposals, which included equipping all public schools with computers, using daytime TV to broadcast training programs (Ilves 1995), making ICT education a key component of compulsory military service, and instituting elaborate forms of digital surveillance for foreign visa holders (Friedrich-Naumann-Stiftung 1996).

In practice, the project evolved into a decade-long effort that provided grants and partial funding for purchasing hardware, developing novel tools for digital education, and offering computing classes for students and teachers. The program was modestly funded--in 1996, it

${ }^{15}$ Jaak Aaviksoo, interview with the author, March 3, 2018. 
awarded, in collaboration with municipal governments, around 50 million kroons in grants (about 5 million USD, or about 2,5\% of the annual budget of the Ministry of Education and Culture). Yet it spurred widespread public debate and opened up avenues for other kinds of municipal and private development. By 2004, the percentage of students who used computers in a classroom setting had jumped to $73 \%$ from just $8 \%$ four years earlier, and, on average, schools had one computer for every twenty students (Toots 2004). The phrase Tiger's Leap became a proxy for Estonia's pathfinding role in the information society transition, and was invoked indiscriminately to describe any qualitative leap: journalists penned articles describing Tiger's Leaps in everything ranging from road construction (Simson 1998) to euthanasia (Kändler 1996). What many participants saw as the project's greatest weakness-its lack of precise definition and ever-shifting set of goals-might have, in fact, been the source of its success, since it allowed a variety of actors to push the program in new directions."

While Ilves initially imagined the Tiger's Leap project as a public-private partnership, with IBM or another computing giant providing the necessary hardware by way of sponsorship, this quickly turned out to be an unrealistic and perhaps undesirable ambition. After a series of cuts and scale-backs during the 1996 economic crisis, the Tiger's Leap ultimately took the form of a stateowned foundation, which dispensed grant funding to evaluated projects submitted by teachers and schools around the country. Schools were required to contribute funding from their own budgets, as well as to seek additional sources, including from municipal governments and the private sector." This structure enabled the foundation to claim a democratic mandate (the investments were, after all, being proposed at the local level, although vetted by a set of experts drawn from ICT companies, the Informatics Council and universities). It simultaneously created a venue for people ranging from elite visionaries to local school administrators to debate the boundaries of the information society, and express broader concerns over the direction of Estonia's development.

Projects actually submitted for Tiger's Leap funding differed markedly from the concerns of the program's primary visionaries. The latter emphasized developing high-tech sectors of the economy through ICT-powered STEM-education. Teachers and organizations submitting proposals, however, were more interested in the humanities and national culture, "safeguarding linguistic culture and human communication," preventing the "onslaught of English in education" and "increasing the number of Estonian language web sites on the Internet."1s While many initial proposals simply requested funding for hardware, data connections, or internationally known educational software, others envisioned developing educational tools specifically for the local context. In its first two years, for example, the Tiger's Leap funded projects for developing computer terminology in Estonia, digitizing Estonian dictionaries and thesauruses, including "the first Estonian dictionary of slang," a history of Estonian literature from 1924-1925, but also digital surveys of Estonian biodiversity and geography.

${ }^{16}$ Enel Mägi, interview with the author, May 8, 2018.

${ }_{17}$ "Tiigrihüppe aastaraamat 1997," ERA.5602.1.2, RA.

${ }_{18}$ “Tiigrihüppe aastaraamat 1997," ERA.5602.1.2, RA. 
Sometimes, Tiger's Leap applications became venues for expressing outrage at the poverty and lack of infrastructure. One petition from a teacher at a rural school in central Estonia, written in 1997, is particularly instructive. Referencing the school's success in applying for some Tiger's Leap programs, the teacher asked for help in solving the "school's grave concerns about computer connectivity." At issue, specifically, was the lack of broadband internet. In explaining the causes of the problem, however, the teacher unfolded a series of complaints about the lack of social and infrastructural development in the region: local phone lines were amortized and had not been replaced, making even dial-up connections unreliable. The school only had "a single blockirated telephone, which goes quiet whenever the weather gets even a little bit more humid." The teacher, who held a second job at the local weather station, traveled only by bicycle, and was taking care of her 83-year old mother, argued that improved infrastructure would help her with all of these tasks. Poor connectivity even hampered communications with the Tiger's Leap foundation itself. The region lacked a functioning library so learning about funding calls became difficult. In short, the teacher connected the need for networking the school to broader issues of poverty and regional inequality, which a functioning Internet connection could at least partly alleviate. The teacher used this exposé to draw attention to "all the small places around Estonia where life is as poor as here, or poorer still," and the fact that the country "was a long way from providing equal opportunities." The teacher's petition was approved, but even more importantly, letters like hers highlighted problems of regional development to experts at the Foundation. They reached out both to the school and Eesti Telefon, and discussed possibilities for giving up to $90 \%$ discounts on broadband connection to rural users. ${ }^{20}$

Such complaints from below, which expanded the meaning of "computerization" from simply hardware purchases and software training to rural poverty, infrastructural underdevelopment, and issues of language and national culture, mirrored expert critiques of the Tiger's Leap program. "It is wrong to take hardware purchases as the starting off point," noted the chairman of the Informatics Council, the cybernetician Ustus Agur in one article, opposing the program's primary visionary, Toomas Hendrik Ilves. A comprehensive program would spend only one third of its budget on hardware, and consider broad infrastructural support (construction of new phone lines etc.) as well as the development of specialized software that began from the specific needs of subject teachers (Agur 1996). Marju Lauristin, the sociologist on the advisory council of the Foundation, highlighted the dangers of creating new forms of inequality ("data-rich" and "data-poor") as well as exacerbating existing regional inequalities." The expansive approach to computerization at the Tiger's Leap foundations was further aided by the preponderance of education experts on its staff and advisory board, who saw ICT development as a means of building "critical thinking skills," training students in "independent collaboration," and putting "creativity first." ${ }_{22}$ The Foundation increasingly prioritized localized software development and

${ }^{19}$ H. I., Letters to the Tiger's Leap Foundation, Nov 29, 1997; Jan 14, 1998; ERA.5062.1.45, RA.

${ }^{20}$ Stenogram of advisory board meeting, Tiger's Leap Foundation, Jan 30, 1998; ERA.5062.1.47, RA.

${ }^{21}$ Stenogram of Informatics Council meeting, Nov 20, 1997, Informaatikanõukogu.1.1-4.4, RIA-A.

${ }_{22}$ Enel Mägi, interview with the author, May 8, 2018. 
specialized training programs over programming classes, and computing classes offered by ICT companies.

The regionalist focus of Tiger's Leap was reinforced by a series of public events called the Tiger Tour, a traveling showcase exhibit of the possibilities of Internet connectivity. Drawing partly on the charisma of its organizer, Linnar Viik (who, in a representative newspaper article, was shown on the roof of his house, surfing the web using a laptop and a cellular phone), and on spectacular displays of computing power (such as having the president of the republic deliver opening remarks via videoconferencing), the Tiger Tour introduced aspects of personal computing specifically to "the 'uncharted territories' of Estonia, which sometimes don't even have electricity" (Sembach-Sakias 1998). The combination of priority setting, activism on behalf of regional coordinators, and consistent PR resulted in rural regions of Estonia actually having a higher per capita number of school computers than the capital, Tallinn, in the year 2000..$^{3}$ The one exception was the predominantly Russian-speaking region of Ida-Virumaa, where Tiger's Leap projects were far and few between. The advisory board wrote this off as a showing a lack of "democratic initiative" on behalf of Russian teachers. ${ }^{24}$ While the Foundation made some efforts directed specifically at recruiting minorities to the program (Salenkov 1998), the lack of attention to ethnic disparities demonstrates the limits of the expansive discourse of information society.

The Tiger's Leap program illustrates how abstract notions of the information society were made concrete through the computerization of Estonian schools. As cyberneticians and sociologists wrote about the importance of state planning in bringing about an information society that reduced inequality and amplified democracy, teachers and activists writing in newspapers (Rummo \& Tavast 1998), participating at conferences, and proposing projects to the Foundation connected these theoretical interventions to practical questions of material deprivation, deteriorating infrastructure, lack of access, and concerns over the health of the Estonian language and national culture. In so doing, they expanded notions of information society and computerization to encompass not simply hardware and STEM-education, but also regional development and poverty. Indeed, by the early 2000s, the Tiger's Leap program was primarily hailed for its attention to the widely ignored problem of regional development (Liivak 1998; Sõnumileht 1998; Liiva 2001; Varik 2003). This frame had serious limits: many things, but not all things, could be connected to questions of computerization, and predominantly ethnic minority regions that were not engaged in Tiger's Leap activities were deprived of a powerful rhetorical tool for calling attention to local poverty. As with many techno-utopian projects, the rhetoric of a Tiger's Leap often obscured a more modest reality. Yet as the boundaries of the information society expanded, this new language did allow new actors to enter the public sphere, and raise concerns that might otherwise have been dismissed as too "Soviet" or "unrealistic."

\footnotetext{
${ }_{23}$ "Tiigrihüppe aastaraamat 2000," ERA.5602.1.7, RA.
}

${ }_{24}^{24}$ Enel Mägi, interview with the author, May 8, 2018. 


\section{Conclusion}

The information society in Eastern Europe has a genealogy that reveals talk of a fundamental divide between socialist cybernetics and Western information society to be a powerful rhetorical tool, but a poor way of representing history. In Estonia, sociologists trained in the 1960s and concerned with providing popular feedback to large-scale efforts at state planning, alongside cyberneticists committed to centralized expertise and oversight, wove a series of disparate ICT development projects into a narrative of an Estonian information society. This discourse was broader and more capacious than visions proposed by international organizations lobbying for the liberalization of telecommunications markets in the former socialist sphere. The "information society" in Estonia became a platform for imagining a bright future, a founding myth, as Toomas Hendrik Ilves put it. At a time when successive governments were focused on rapid privatization and liberal economic reforms (Vetik 2012), it offered a language in which questions of inequality, state planning, responsibility, and democratic participation could be articulated, as well as envisioning the means for potentially addressing them.

Whether one looks at Leningrad and Tartu sociologists drawing inspiration from American public opinion researchers in the 1960s, Soviet cyberneticians working with Finnish companies in the 1980s, or ICT visionaries developing the Tiger's Leap with Open Society and UNDP funding in the 1990s, one is struck by the close collaboration of Soviet and Western experts, their ability to make each-others' priorities mutually intelligible, while simultaneously denouncing certain kinds of expertise as illegitimate because of their provenance from the wrong side of the Iron Curtain. Lots of rupture-talk was generated in those years, but very little rupture. While historians have called for thinking of cybernetics as a transnational story (Edina 2011; Rindzevičiūte 2016), much of the scholarship has remained focused on showing how innovators, users, and governments tried to used computing to imagine a Chilean road to socialism, a Soviet form of central planning, or a Californian libertarian utopia. Focusing on how actors across ideological and intellectual divides coordinated their goals, and exchanged and translated information may yield a better understanding of how visions of information societies were put into practice. It may, indeed, be a more cybernetic approach.

To what degree ICT development can actually alleviate democratic deficits and material deprivation is, of course, an ongoing debate. The Estonian example is not a particularly encouraging one. After the Tiger's Leap, a series of attempts at organizing digital participatory governance have been attempted and discarded, from the 2001-era web platform Today I Decide to the 2013 People's Assembly to the ongoing Citizen Initiative Portal (Velmet 2015). Here, too, familiar tensions abound between reformers focused on engineering more attractive and easy-touse platforms, and critics who emphasize the importance of political support, civic education, equal access, and "offline" grassroots organizing, which ICT can support and amplify, but not replace. Ironically, while international publications have now taken note of Estonia's digital development, local critics are increasingly starting to shift the e-state's focus on public service software to include issues ranging from accessibility to regional and ethnic inequality. The legacy of cyberneticians-sociologists remains relevant still. 


\section{Author Biography}

Aro Velmet is assistant professor of European history at the University of Southern California. He is the author of Pasteur's Empire: Bacteriology and Politics in France, its Colonies, and the World. He is currently working on a global history of socialist cybernetics.

\section{Acknowledgements}

The project leading to this article has received funding from the European Union's Horizon 2020 research and innovation program under the Marie Sklodowska-Curie grant agreement No 747591. The article has also received support from the Estonian Research Council grant PRG346. The author would like to thank Marek Tamm, Uku Lember, Laur Kanger, Marysia Jonsson, Katherine Marino, Egle Rindzevičiūtè, Jacob Ward, and the reviewers for excellent comments on various versions of this article.

\section{References}

Aaviksoo, J. 1996. "Arvutitiiger jääb ellu." Eesti Päevaleht. Oct. 1.

Abbate, J. 1999. Inventing the Internet. Cambridge: MIT Press.

Afinogenov. G. 2013. "Andrei Ershov and the Soviet Information Age." Kritika: Explorations in Russian and Eurasian History. 14(3). Summer. 561-84.

Aedla, M. 1996. "Arvutikoolitus." Kaubaleht. February 19.

Agar, J. 2003. The Government Machine. A Revolutionary History of the Computer. Cambridge: MIT Press.

Agur, U. 1996. "Eesti riigi tiigrihüppest arvutiajastusse." Äripäev. March 24.

Ames, M. \& Warschauer, M. 2010. "Can One Laptop Per Child Save the World's Poor?" Journal of International Affairs. Fall / Winter 2010. Vol. 64, No. 1. 33-51.

Annist, A. 2011. Otsides kogukonda sotsialismijärgses keskuskülas. Arenguantropoloogiline uurimus. Tallinn: Tallinn University Press.

Barry, A. 2001. Political Machines: Governing a Technological Society. London: The Athlone Press.

Breckenridge, K. 2014. Biometric State: The Global Politics of Identification and Surveillance in South Africa, 1850 to the Present. Cambridge: Cambridge University Press.

Castells, M. 2010. The Rise of the Network Society: Economy, Society and Culture v.1, 2nd edition. New York: Wiley-Blackwell.

Chakravorti B., Tunnard C., and Shankar C, R. 2015. "The Way to Estonia. How to Reach Digital Nirvana." Foreign Affairs. Mar. 24.

Crouch, D. 2015. "How Estonia set the pace on the way to digital government." The Financial Times. June 5.

Danilova, E. N., Kozlova L. A.; Kozyreva, P. M.; Kolbanovskii, V. V. \& Oberemko, O. A. 2009. Vivat, Iadov! : 80-letnemu iubileiu. Moscow: Uchrezhdenie Rossiskoi Akademii Nauk. 
Eesti Inimarengu Aruanne. 1996. Tallinn: UNDP.

Eesti Inimarengu Aruanne. 1999. Tallinn: UNDP.

Edwards, P. N. 1996. The Closed World: Computers and the Politics of Discourse in Cold War America. Cambridge: MIT Press.

Eesti Ekspress. 1996. "'Tiigrihüpe' viskab Eesti üle Soome lahe." March 22.

Erickson, P., Klein, J. L., Daston, L., Lemov, R., Sturm, T., and Gordin, M. D. 2013. How Reason Almost Lost Its Mind: The Strange Career of Cold War Rationality. Chicago: University of Chicago Press.

Ershov, A. P. 1988. "Informatizatsiia: Ot komp iuternoi gramotnosti uchashchikhsia k informatsionnoi kul'ture obshchestva," Kommunist. No. 2

Ferguson, J. 1994. The Anti-Politics Machine: 'Development,' Depoliticization, and Bureaucratic Power in Lesotho. Cambridge: Cambridge University Press.

Friedrich-Naumann-Stiftung. 1996. Eesti tee meediaühiskonda. Konverents Tallinnas 9. märtsil 1996. FNS: Tallinn.

Gerovitch, S. 2002. From Newspeak to Cyberspeak: A History of Soviet Cybernetics. Cambridge: MIT Press.

Guilhot, N., and Bessner, D. 2019. The Decisionist Imagination: Sovereignty, Social Science and Democracy in the 20th Century. New York: Berghahn Books.

Hecht, G. 2012. Being Nuclear: Africans and the Global Uranium Trade. Cambridge: MIT Press.

Heidmets, M., Niit, T., Liimets, H., 1983. Chelovek v social'noj i fizicheskoj srede. Tallinn: Akademia Nauk ESSR.

Heller, N. 2017. "Estonia, the Digital Republic." The New Yorker. Dec. 18.

Högselius, P. 2005. The Dynamics of Innovation in Eastern Europe: Lessons from Estonia. Cheltenham: Edward Elgar.

Hughes, T., Bijker, W. and Pinch, T. J. 1987. The Social Construction of Technological Systems: New Directions in the Sociology and History of Technology. Cambridge: MIT Press.

Iadov, V. 1970. Sotsioloogilise uurimise metodoloogia ja protseduurid. Tartu: [mimeograph]

Iadov, V. 1972. Sotsiologicheskoe issledovanie: metodologiia, programma, metody. Moscow: Akademia Nauk SSSR.

Igo, S. E. 2008. The Averaged American: Surveys, Citizens, and the Making of a Mass Public. Cambridge, MA: Harvard University Press.

Ilves, T. H. 1995. "Eesti riigi tiigrihüppest arvutiajastusse." Äripüev. March 24.

Johnson, J. 2017. Priests of Prosperity: How Central Bankers Transformed the Postcommunist World. Ithaca: Cornell University Press.

Kanger, L. 2013. "Domestic PC production in the Soviet Baltic States 1977-1992." Ph.D. Diss. University of Edinburgh. Accessed February 21, 2020. https: / / ethos.bl.uk/OrderDetails.do?uin=uk.bl.ethos.693573

Keen, A. 2016. "E-stonia: the country using tech to rebrand itself as the anti-Russia." The Guardian. Apr. 21. 
Kimmo, M., Pappel, I, and Draheim, D. 2018. „E-Residency as a Nation Branding Case.“ ICEGOV '18: Proceedings of the 11th International Conference on Theory and Practice of Electronic Governance. April. 419-428.

Kurg, A. 2019. „Free Communication: from Soviet Future Cities to Kitchen Conversations.“ The Journal of Architecture. 24(5). 676-698.

Kutser, M., ed. 2000. Küberneetikainstituut muutuvas ajas. Tallinn: TTÜ.

Kändler, T. 1996. “Tiigrihüpe eutanaasias.” Eesti Päevaleht. Oct 10.

Kübi Aastaraamat. 1990. Tallinn: TTÜ.

Lagerspetz, M. 2007. Sotsioloogia--peatükk Eesti kultuuriloost. http:/ / users.abo.fi/mlagersp/SotsAjalEestis2007.pdf. Last Accessed on June 18, 2018.

Langemets, A. 1994. "See mis meist saab see selgub." Hommikuleht. Sept. 10.

Larkin, B. 2008. Signal and Noise: Media, Infrastructure, and Urban Culture in Nigeria. Durham: Duke University Press.

Lauristin, M. \& Vihalemm, P. 1977. Massikommunikatsiooni teooria. Õppevahend žurnalistika üliõpilastele. Tartu: Tartu Riiklik Ülikool.

Lauristin, M. 2010. Punane ja Sinine. Tallinn: Eesti Ekspress.

Leeds, A. 2016. "Dreams in Cybernetic Fugue: Cold War Technoscience, the Intelligentsia, and the Birth of Soviet Mathematical Economics." Historical Studies in the Natural Sciences. 46(5). 633-668.

Light, J. S. 2003. From Warfare to Welfare: Defense Intellectuals and Urban Problems in Cold War America. Baltimore: Johns Hopkins University Press.

Liiva, A. 2001. "Tiigrihüpe tasandab lõhet maa ja linna vahel." Õpetajate Leht. Sept 28.

Liivak, S. A. 1998. "Muinasjutt Tiigrimaast muutub tegelikkuses." Oppetajate Leht. May 15.

Mailland, J. \& Driscoll, S. 2017. Minitel: Welcome to the Internet. Cambridge: MIT Press.

Margetts, H. 1998. Information Technology in Government: Britain and America. London: Palgrave MacMillan.

Medina, E. 2011. Cybernetic Revolutionaries: Technology and Politics in Allende's Chile. Cambridge: MIT Press.

Medina, E.; da Costa Marques, I. \& Holmes, C., eds. 2014. Beyond Imported Magic: Essays on Science, Technology, and Society in Latin America. Cambridge: MIT Press.

Mirowski, P. 2001. Machine Dreams: Economics Becomes a Cyborg Science. Cambridge: Cambridge University Press.

Mirowski, P., and Nikh-Khah, E. 2017. The Knowledge We Have Lost in Information: The History of Information in Modern Economics. New York: Oxford University Press.

Murutar, A., ed. 1995. Maarahva elujõud—müüdid ja tegelikkus. Tartu: Elmatar.

Oja, A. \& Raukas, A. 1999. Eesti 21. sajandil. Arengustrateegiad, visioonid, valikud. Tallinn: TA Kirjastus.

Osipov, G. V. 2009. “The Rebirth of Sociology in Russia: How It Actually Developed.” Russian Social Science Review. 50(6). 80-108.

PBS Newshour. 2018. "How Estonia built a digital first government." Apr. 29. Accessed on June 7, 2018. https:/ / www.pbs.org/newshour/show/how-estonia-built-a-digital-first-society 
Peters, B. 2016. How Not to Network a Nation: The Uneasy History of the Soviet Internet. Cambridge: MIT Press.

Praust, V. 1996. "Eesti (tiigri)hüpe maailma?" Sõnumileht. March 25.

Riigikogu, Republic of Estonia. 1998. "Eesti infopoliitika põhialused." Riigi Teataja. I 1998, 47, 700.

Rebane, K. 2011. How a Foundation Helped to Lay the Foundation for E-Estonia. Open Estonia Foundation: Tallinn.

Rindzevičiūtè, E. 2016. The Power of Systems: How Policy Sciences Opened Up the Cold War World. Ithaca: Cornell University Press.

Rumm, H. 1998. “Riigipoolsed teenused elektrooniliseks.” Eesti Päevaleht. March 22.

Rummo, T \& Tavast, A. "Tiigrihüpe tegelikkuses." Arvutimaailm. January issue.

Ruut, J. 1996. "Tiigrihüppest." Arvutustehnika ja Andmetöötlus. November issue.

Salenkov, M. 1998. “Doprygnet li tigr do russkoj gimnazii?” Estonija. Dec 3.

Sampere. J. P. V. 2016. "Why Estonia Is Letting Entrepreneurs Become "E-Residents."” Harvard Business Review. March 9. Accessed February 21, 2020. https://hbr.org/2016/03/whyestonia-is-letting-entrepreneurs-become-e-residents

Sembach-Sakias, I. 1998. „Tiigrituur aitab edendada kohalikke võrguühendusi.“ Eesti Päevaleht. August 30.

Scott, M. 2014. “Estonians Embrace Life in a Digital World." The New York Times. Oct. 8.

Simson, M. 1998. „Majanduse tiigrihüpe otsas.“ Eesti Päevaleht. Dec. 31.

Soros, G. 1990. Opening the Soviet Society. London: Weidenfeld \& Nicolson.

Shlapentokh, V. 1982. „The Study of Values as a Social Phenomenon: The Soviet Case.“ Social Forces. 61(2). December. 403-417.

Sembach-Sakias, I. 1998. "Tiigrituur kutsub Internetti surfama." Eesti Päevaleht. August 23.

Tammet, T. 1997. "Tiigrihüppe õppetunnid." Eesti Päevaleht. Ärileht. June 20.

Terk, E. \& Raagmaa, G. 1997. Eesti Tulevikustsenaariumid. Tallinn: Keskkonnaministeerium.

Ther, P. 2016. Europe Since 1989: A History. Transl. Hughes-Kreutzmüller, C. Princeton: Princeton University Press.

Toots, A. 2004. Tiiger luubis lõpprapport. Tallinn: Tiigrihüppe SA.

Turner, F. 2006. From Counterculture to Cyberculture: Stewart Brand, the Whole Earth Network, and the Rise of Digital Utopianism. Chicago: Chicago University Press.

Varik, M. 2003. "Tiigrihüppe sära ja hariduse infosüsteemid." Opetajate Leht. Oct. 3.

Velmet, A. 2015. “E-kodanikud ja e-tarbijad. Kaks lugu 21. sajandi eestlusest." Vikerkaar. Oct-Nov. 139-147.

Velmet, A. 2016. "Networking the Nation: The Politics of Digital Infrastructure in Estonia," Kārlis Bērziñš et al. eds. The Baltic Atlas. Berlin: Sternberg Press. 180-190.

Velmet, A. 2019. "When Demography becomes Democracy: Anticommunism, Sovereignty and the Problem of Reproduction in Estonia, 1980-2016." The Journal of the History of Ideas 80(3), July. 455-478.

VentureBeat. 2018. "Forget Silicon Valley; tiny Estonia is reimagining the way money moves." June 11, 2018. Accessed on February 21, 2020. https://venturebeat.com/2018/06/11/forgetsilicon-valley-tiny-estonia-is-reimagining-the-way-money-moves / 
Vetik. R., ed. 2012. Nation-Building in the Context of Post-Communist Transformation and Globalization. The Case of Estonia. Frankfurt am Main: Peter Lang Verlag.

Weekes, A. L. 2019. "Digitizing Nation-State: Nationalism, Citizenship, and Sovereignty in eEstonia." PhD Diss. Stanford University. 